\title{
The Wise Book of Astronomy and Philosophy IN LONDON, WELLCOME LIBRARY, MS 411 (FF. 32R-37v)
}

\begin{abstract}
London, Wellcome Library, MS 411 is a one-volume codex from the late fifteenth century which holds a collection of short treatises and tracts in English and Latin on different topics including prognostications, nativities, bloodletting, medical astrology, among others. In this article, the anonymous Wise Book of Astronomy and Philosophy, written in English and held in folios $32 \mathrm{r}$ to $37 \mathrm{v}$, is taken into consideration. The objective is threefold: (i) to examine the contents, transmission and sources of the text, (ii) to describe it from a physical standpoint, and (iii) to analyse the text's main dialectal features in order to establish a likely place of composition. Investigation on these aspects can throw some light on the function and transmission of the text, and may also prove significant for a better understanding of it.
\end{abstract}

Keywords

MS Wellcome 411; Middle English; astronomy; astrology; philosophy; mediaeval medicine

\section{Introduction}

The Wise Book of Astronomy and Philosophy (hereafter WBAP) was a popular text during the later Middle Ages, as the number of extant witnesses shows. ${ }^{1}$ However, research and editions of them are virtually non-existent. As of yet, the text has only been published in two printed editions, namely, those by Krochalis and Peters (1975) and Griffin (2013). ${ }^{2}$ There are also two unpublished $\mathrm{PhD}$ theses (Grothé 1982; Griffin 2006) and one MA dissertation (Southmayd 1970) offering 
editions of different witnesses of the text. The study presented in the following pages focuses on the version held in London, Wellcome Library, MS 411, ff. 32r$37 \mathrm{v} .{ }^{3}$ Attention is paid to the treatise's contents and codicological/palaeographical features; the language of the text is also assessed by taking into account a number of linguistic features (represented by specific forms or occurrences of words) in an attempt to establish the most likely dialectal location of the scribe of the text.

MS Wellcome 411 is a one-volume codex which houses a collection of short treatises and tracts in English and Latin, some in verse, on different topics including prognostications, nativities, medical astrology, reproduction, how to deal with the bites of animals, bloodletting, etc. The detailed contents of the codex are as follows: ${ }^{4}$ Prognostication according to the day on which Christmas Day falls (ff. 1r-2r; anonymous); Dietarium salutissimum (ff. $2 \mathrm{v}-3 \mathrm{v}$; anonymous); Treatise on lucky and unlucky days (ff. 4r-9r; anonymous); Book of nativities (ff. $9 \mathrm{v}-18 \mathrm{v}$; anonymous); On perilous days (ff. 18v-19r; anonymous); Almanac (ff. 21r-26v); Flores dietarum (ff. 27r-30r; anonymous); WBAP (ff. 32r-37v; anonymous); Notes and extracts on medical astrology (ff. 38r-51v; anonymous); De conferentibus et nocentibus (ff. 52r-53r; Arnold of Villanova); De coitu (ff. 53r-56r; Constantine the African); On venomous bites (ff. 56r-61r; anonymous); Canon pro minutionibus et purgationibus recipiendis (ff. 61v-63r; Nicholas of Lynn). Some of the texts are extracts or abridged versions and, as can be seen, most of them remain anonymous. All the texts date from the late fifteenth century.

\section{Contents, transmission and sources}

Folios $32 \mathrm{r}$ to $37 \mathrm{v}$ hold the $W B A P$, which deals with astrology and cosmology. It contains a description of the seven planets and twelve signs of the horoscope, the latter including an allegorisation of the zodiac in terms of Christian symbolism and basic rules for determining a nativity according to the sign in which the person was born. It also describes the eleven heavenly spheres, provides an account of the theory of humours, elements and complexions (which would be associated with the medical applications of astrology). And finally, it explains the governing of the planets, offering more elementary directions for establishing a nativity, this time taking into account the day of the week in which the person was born. With the exception of the allegorised zodiac and its predictions, the rest of the contents are to be found in a great number of late mediaeval and early Renaissance miscellanies and scientific manuscripts.

The text in the WBAP is anonymous and there is no evidence of the identity of the author, translator and/or compiler who wrote it, or of the scribe who copied it. The witness under consideration was written around 1475-1500, so it is rather late when compared to other copies dating from ca. 1400 (see Keiser 1998: 3766-3767). Concerning the manuscript, there is not either definite proof of provenance, although the names and information found in several folios ("Doctor rydle byschoppe of London" [f. 19r]; "Recyvyd of my master Wylliam Watnor 
the sum of iii li. xiij s. iiij d. and a quarters wagys" [f. 30r]; "Wyllyam Davy" and "Thomas champe", "Georg Sheffeld" [f. 63v], etc.) and later additions demonstrate that it passed through a number of hands. Thus, the account on folio 30r indicates that at some point in the sixteenth century the manuscript was being used by a man employed by a certain William Watnor and the signatures on folio $63 \mathrm{v}$ show that it was in circulation at the beginning of the seventeenth century. The manuscript was purchased at Sotheby's in 1929 and since then has been housed at the Wellcome Library (see Southmayd [1970: v-viii] for further details).

The tract at issue might have been used by a physician who practised during the late Middle Ages. Mediaeval doctors believed in astrological medicine. According to Talbot (1967: 127), this "presented an aspect of precise and coordinated knowledge based on an accurate, determined, and predictable order of the heavens. It was 'scientific' in that it was based on principles elaborated during classical times and handed down almost unchanged in the later centuries". This connection is illustrated in two lines taken from the opening folio (32r) of the tract: "for per is no leche in pis worlde · pat may truly · with $\mid$ his crafte · but yf he haue pe science and be kunnyg of pis boke" ("for there is no doctor in this world that may truly know his craft unless he has the science and the teaching of this book"). The fact that the $B W A P$ occurs alongside medical texts in MS Wellcome 411 is evidence that the tract served a utilitarian function.

In the mediaeval period, there was a certain amount of overlapping between astronomy and astrology and both sciences were an important element in science, religion, medicine and art. In fact, the tract is called "Book of Astronomy" despite the fact that it deals mostly with astrology. This is crucial to understand its cultural context. Ptolemy, ${ }^{5}$ one of the most influential early writers on astrology, divided it into two main parts, as Arabic astrologers did: the movement of the stars, on the one hand, and the science of the judgements of the stars, on the other. The former took into account the theory of the heavens, whereas the latter involved its practical application to the world below. This seems to correlate with the modern distinction between astronomy and astrology, although "there was no real semantic separation between the two terms in the middle ages and renaissance, and both words are used more or less interchangeably throughout the period" (Carey 2010: 889).

The early church considered astrology to be associated with the devil and to be a pagan science. It was not until the late Middle Ages that astrology became in fact an accepted area of study and an important force in mediaeval culture after the recovery of the texts by Greek philosophers, such as Aristotle, in the twelfth century, which gave it scientific prestige. In the tract, the opening lines make reference to this Greek source (f. 32r):

h ere by் gẏnnythe pe boke of Astronomy · and of filosophye | conteyned and y made of pe wysest filosofers and Astromysers | pat euer were sẏp pe worlde was be gun · pat is for to say · of pe lond | of Greke · for in pat lond · an ynglyshe man fulle wyse and welle vn // | derstonde of filosofye and of astronomye studyed and compiled pis | boke oute of grwe in to ynglyshe · graciously · ("Here begins the book of astronomy and of philosophy contained 
and made of the wisest philosophers and astronomers that were ever since the world was begun, that is to say, of the land of Greece, for in that land, a very wise Englishman and wellinstructed in philosophy and in astronomy studied and compiled this book out of Greek into English, graciously"; my emphasis).

This prologue locates the $W B A P$ "in a learned, translated tradition of philosophical writing, and [ensures] that the translator figure [...] is both reliable and scholarly" (Griffins 2013: lviii), although the assertion that the book was compiled from Greek remains questionable and might have been used only for the purpose of raising prestige to the work. Reference to philosophers is found throughout the text, such as the one on folio $34 \mathrm{r}$ : "Hevyn is devydid in to $\cdot \mathrm{xj} \cdot$ speres $\cdot$ and $\mathrm{pat} \mathrm{ma} / / \mid \mathrm{kythe} \cdot \mathrm{xj} \cdot$ heuennes $\cdot$ as hit is a forsayde $<_{\wedge}$ by be filosofris $>[\ldots]$ " ("Heaven is divided into eleven spheres and that makes eleven heavens, as it was said by the philosophers" [...]; my emphasis).

Astrology was integrated into encyclopaedic works such as Bartholomaeus Anglicus' On the properties of things, dating from the early-mid thirteenth century (Seymour et al. 1975-1988), and in medical works. The importance of the humoural theory, which dominated mostly late mediaeval science and medicine in particular, is emphasised on folio $32 \mathrm{r}$ :

"pis boke tellythe $[\ldots] \mid[\ldots]$ of pe Elementes $\cdot$ and pe complexiouns and of pe manerys of mane $\mid$ with oute pe whyche science and knoulyche no man may kun · ne com | to pe perfite wyrkyng of astronomye · fysik ne surgen · ne of oper | sotelle science" ("this book tells $[\ldots]$ of the elements, the complexions and the manners of man; without this science and knowledge no man may know or understand the complete working of astronomy or of other complex science, neither physician nor surgeon").

The four humours of Hippocratic medicine included blood, phlegm, choler or yellow bile, and melancholy or black bile. It was believed that the Universe was composed of four elements: fire, air, water and earth, which, in turn, had different qualities. The humours were also present in the human body and depending on their prevalence, a person could be sanguine, phlegmatic, choleric or melancholic; each type of individual had a different "complexion" or temperament.

Allusion to the complexions is made in one of the sections in which nativities in terms of days of the week are discussed. Nativities were one the branches of the science of the stars and assessed the influence of the celestial bodies at the time of birth. Thus, we find on folio $37 \mathrm{r}$ that: "Who so is born on pe tuysday · vnder pe constellacion of mars $\cdot \mid$ he shalle be coleryk $\cdot$ strong wrathefulle $\cdot \operatorname{cou}_{\wedge}<\mathrm{e}>$ tous - a man sleyer | a traytur / and ryche" ("Whoever is born on a Tuesday under the constellation of Mars shall be choleric, easily given to anger, greedy, a murderer and a traitor, and rich"; my emphasis); or that: "Who so is born on pe thurysday . vndere pe constellacion of Ju// | biter ' he shalle be Sanguỷn · lovyng · benevolle and wyse" ("Whoever is born on a Thursday under the constellation of Jupiter shall be sanguin, loving, kindly disposed and wise"; my emphasis). 
Another remarkable socio-cultural feature of the tract is the allegorisation of the zodiac. Thus, the stars are christianised by means of comparisons or by the inclusion of ideas relating to Christianity. This can be seen as a way to remove the pagan influence which permeates the text. Let us take for example the first sign described, Aries, on folio 32v: "And first of alle reygnythe - Aries · in | pe mounthe of marche - for in pat sygne god made be worlde 9 And $\mid$ in pis sygne - Aries is clepid · pe sygne of a ram - for as mychille | as Abraham made his offryng to god of a ram · for his sun ysaac //" ("And first of all Aries governs in the month of March for in that sign God made the world. And this sign Aries is called the sign of a ram because Abraham made his offering to God of a ram for his son Isaac"; my emphasis). The fifth sign, Leo, governs in July "and is clepid pe signe of a lyon - for as $\mid$ myche as danielle pe prophete $\cdot$ was put in to a depe pyt · a | "mong lyouns //" ("and is called the sign of a lion because Daniel the prophet was put into a deep pit among lions"; my emphasis).

Other allegories include Job the leper for Cancer, the Virgin Mary for Virgo, Judas Iscariot for Libra, King David for Sagittarius, Saint John the Baptist for Aquarius or the prophet Jonah for Pisces.

\section{Codicological/palaeographical analysis}

The physical features described in this section refer to those folios in which the WBAP is held. The text, in a single column, is written in the same clear book hand throughout, and the handwriting is neat and careful. The number of lines per folio is uniform as it has 31 lines (except the last folio which has only 11 and another one with 30 lines).

The manuscript has been refoliated in pencil, at the top of the folio, on the right-hand side of each recto. Folios are ruled in order to aid the scribe to keep a regular line of writing. Signs of pricking, which involves the piercing of a series of holes on the leaf to assist with the ruling of lines, are evident on the right of rectos and left of versos.

The script is mixed, showing features from the Anglicana and Secretary scripts. A typical Anglicana letter-form is the tight $g$ (see Figure 1), ${ }^{6}$ sometimes described as shaped like the numeral 8 and resembling a pair of spectacles seen sideways on, and long forked $r$, descending below the line of writing (see Figure 2). As for the Secretary script, one of the characteristic letter-forms that distinguishes it from Anglicana is the neat single-compartment or single-lobed $a$ with a pointed head (see Figure 1). Different Secretary forms of $r$ are commonly found in any position within the word (see Figure 2).

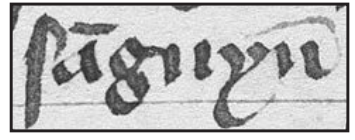

Figure 1. sanguyn 


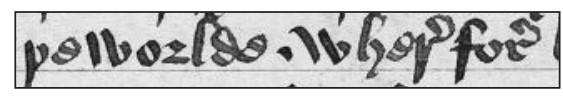

Figure 2. pe worlde $\cdot$ where fore

Abbreviations are frequent, as in most mediaeval scientific manuscripts. Their main function is to save time and writing space. The majority of them are standard, such as the symbols for $<$ ua $>$ (Figure 3), $<$ es $>$ (Figure 4), $<$ er $>$ (Figure 5) and $<$ us $>$ (Figure 6).

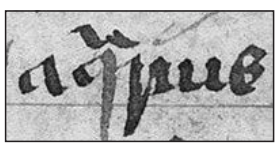

Figure 3. aquarius

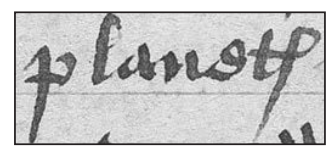

Figure 4. planetes

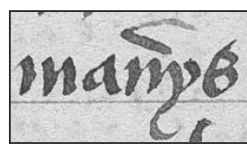

Figure 5. manerys

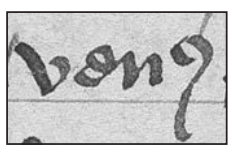

Figure 6. venus

The same symbol can be employed for different letters or groups of letters, as in 'sanguine' (Figure 7) or 'circulus' (Figure 8): the sign represents both the vocalic group $<\mathrm{ui}>$ and the consonantal cluster $<\mathrm{ri}>$. A similar case takes place with expansion marks indicating a nasal, which may signify $<\mathrm{m}>$ or $<\mathrm{n}>$ (see Figures 9 and 10).

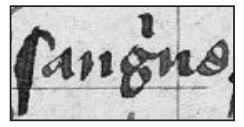

Figure 7. sanguine

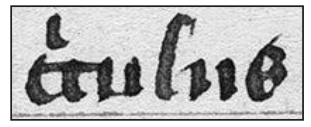

Figure 8. circulus

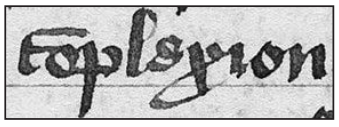

Figure 9. complexion

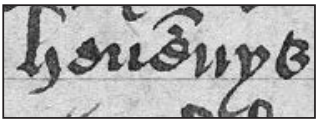

Figure10. heuennys

Folios do not contain any type of decoration. A space has been left for a two-line initial at the beginning of the tract (Figure 11), although for unknown reasons (maybe lack of time or of money), it has not been finally completed.

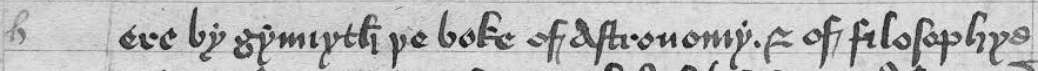

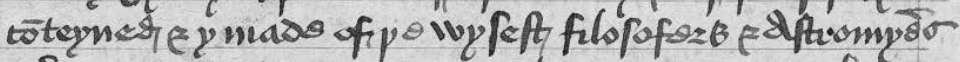

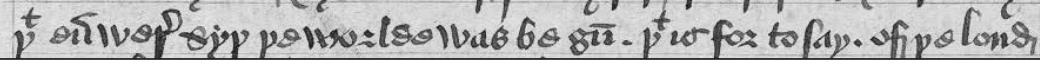

Figure 11. Incomplete initial

Marginalia are frequent and contemporary to the main text. Some of the annotations are key words making reference to what is being dealt with in the text, thus acting as textual markers to help the reader find information quickly. Scribal corrections can also appear in the margins, which can be employed to write a word or words that have been left out in the process of copying the text. Since they are common, this somehow implies a not very careful scribe (Figure 12). Both the 
lack of decoration and the presence of marginalia suggest a practical function of this particular witness of the tract.

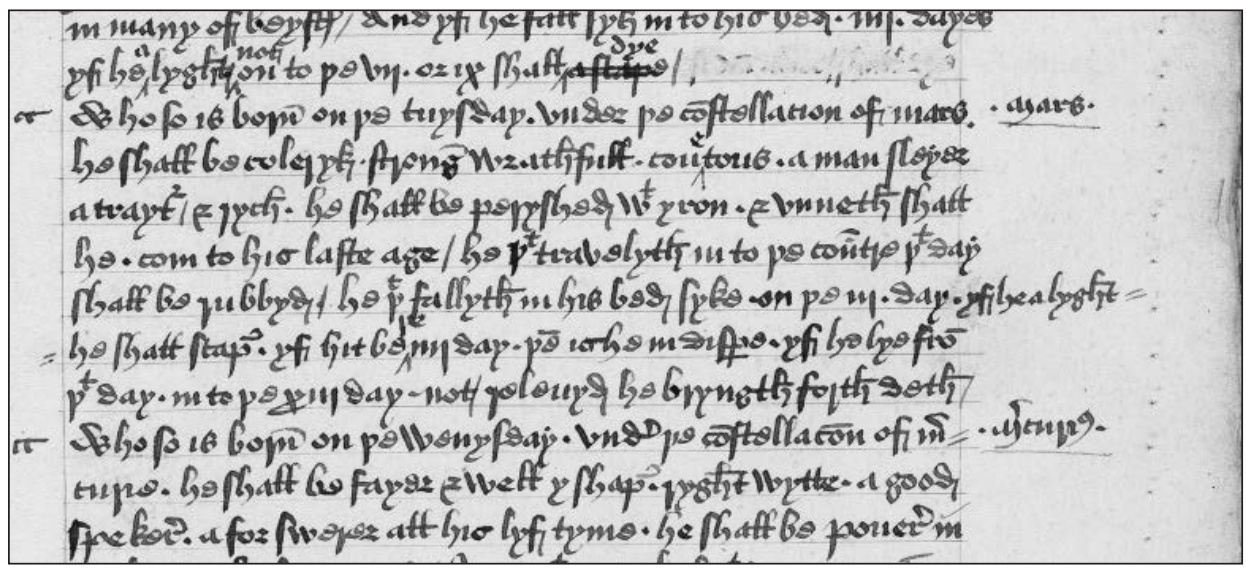

Figure 12. Marginalia

\section{Dialectal analysis}

A preliminary and cursory examination shows that the language of the WBAP in MS Wellcome 411 is quite standardised. Thus, for example, the forms 'many', 'any'/'ony', 'yf' and 'throughe', which are found in the text, are widespread and were common throughout the whole territory. Therefore, a more in-depth analysis including dialectal fitting is mandatory to localise the text geographically in an accurate way. The method of analysis is based on the model proposed in the Linguistic Atlas of Late Mediaeval English (McIntosh et al. 1986), LALME for short, which consists of several steps. The first of them was the completion of a survey questionnaire made up of items (which could be defined as headwords or lemmas) and their different forms of realisation. The set of items was selected from the list provided in volume 3 (pp. xviii-xix) of $L A L M E$, taking into account those items for which there were forms in the text and which, in principle, may supply salient written variants.

The $W B A P$ had been previously transcribed, lemmatised and morphologically tagged by the author of this article. The process of lemmatisation and morphological tagging of the text enabled the retrieval of all the occurrences (or forms) of items with the aid of the software tool Text Search Engine (Miranda-García and Garrido-Garrido 2012). For the display of results, some changes were introduced to $L A L M E$ 's bracketing system (see vol. 3: xiv), in which variants "not enclosed by parentheses stand in dominant frequency". Thus, for each item all the corresponding forms were provided with the number of occurrences in decreasing order of frequency. The completed questionnaire has allowed devising the Linguistic Profile (LP) of the text (see Appendix I). 
The next phase involved the application of the 'fit'-technique (McIntosh et al. 1986, vol. 1: 10-12; Benskin 1991), whose mechanics include the use of dot maps, in which forms are plotted in successive transparent overlays in order to restrict the area of origin, and of item maps for a more precise dialectal localisation. Once this has been done, the LP attained can be compared with other LPs to support the ascription of the text. The county dictionary may also be employed for variants not gathered in maps. Attested forms in the text from the LP were chosen and checked against LALME's dot maps (vol. 1). Next, to narrow down the likely area of provenance and determine the exact location of items' variants, a set of them was selected and examined against the corresponding item maps in LALME (vol. 2). An overlay of tracing paper, in which dominant and minor variants were registered, was employed for the purpose.

Two types of localisation, broad and narrow, have been pursued. Firstly, for broad localisation general features of the language and a few items were considered in order to give a rough approximation of the area of origin and circumscribe it to one, if possible, of the traditional five regional dialects of Middle English (Northern, West Midland, East Midland, South-Western and South-Eastern) (Brook 1978: 60). Then, for narrow localisation a larger number of items were analysed so as to pinpoint a more precise dialectal location.

With regards to broad localisation, the rounding of $\mathrm{OE} \bar{a}$ to $\bar{o}$ in words such 'stone' (OE stān 'stone') and 'hole' (OE hāl 'whole') led to the ruling out of the North. According to Brook (1978: 63), one of the most evident features of Northern dialects is that $\mathrm{OE} \bar{a}$ was not rounded and it was represented in spelling as $<\mathrm{a}>$. Another evidence to support this exclusion of the North is the presence of final - $e$ in a number of words ('gote' ['goat'], 'duke' ['head'], 'dissese' ['discomfort'], 'syde' ['side']). The loss of final - $e$ occurred much earlier in the North than in other parts of the country and this loss is usually reflected in spelling (Brook 1978: 64).

Among the features surveyed in the dot maps, the primary and secondary variants for items MUCH (endings of the '-ch(e)' type, forms ending in -ell or -elle and forms ending in -ill(e) or -yll(e): 'myche' [13×], 'mykelle' [2×], 'mykylle' [2×], 'mýche' $[1 \times]$, 'mychille' $[1 \times]$ ), together with the variants of THOUGH (forms with ou, ov or ow: 'thoughe' $[2 \times]$, 'thowe' $[1 \times]$ ) and $\mathrm{CHURCH}$ ('chir-' and 'chyr-' types: 'chirche' $[1 \times])$, have corroborated this restriction of the geographical location of the text to the Midlands and South. Likewise, the forms 'ho' for the word 'who' also limits the text to the above-mentioned areas. There is not, however, a precise or evident zone in which the forms for items conflate the most but, on the contrary, they are quite extended throughout.

Other items such as THESE, IT, SUCH, ANY, WAS, SHALL, SHOULD, FROM, THERE or WHERE were of little help, as the forms found for them in the WBAP were common throughout the whole territory (see Appendix I).

The general absence of prefixal marking for past participles (104 out of 111 instances of past-participle forms do not contain a prefix; e.g., 'clepid', 'declaryd', 'made', 'ordeyned', 'put', etc.) is peculiar to the Midlands (Mossé 1952: 81-86), although the $y$-prefix does also occur. The use of this $y$-prefix, which is found on 
6 occasions (e.g., 'y made', 'y ordeyned', 'y sett', 'y shape), is also common in the South (Smith 2005: 121).

Personal pronouns have also proved useful for broad localisation; accordingly, the forms for the subject and object case ('bey' and 'hem', respectively) of the third person plural pronouns represent a mixed type (with a Scandinavian subject form and a native object form), which is typical of the East Midlands (Smith 2005: 120).

If phonological features are taken into consideration, such as Old English [y], which became unrounded and represented in spelling by means of $<\mathrm{i}>$ or $\langle\mathrm{y}\rangle$ in the East Midlands and the North (Mossé 1952: 23), we find in the text the words 'kynd(e)' (OE cynd) and 'kyng' (OE cyning), but the words 'evelle' (OE yfel) and 'kernelle' (OE cyrnel) also occur. This <e > spelling, on the other hand, was typical of the South-East.

Before resorting to the item maps, it was necessary to further reduce the geographical stretch. Therefore, a closer look was taken at the items corresponding to the third person singular and plural of the present indicative in the LP.

As far as the third person singular is concerned, it must be mentioned that, in the transcription of the text, the horizontal stroke through $h$ in words ending in th was expanded to $e$ for consistency's sake, although this was done with the understanding that the stroke may represent an otiose mark (see Figures 13 and 14).

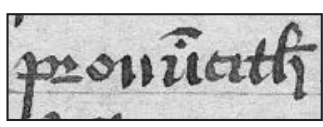

Figure 13. pronuncithe

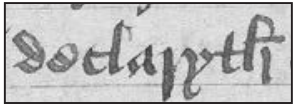

Figure 14. declarythe

Present forms of the anomalous verb be and the verbs may and shall are not included in the count of items $3^{\text {RD }}$ PERSON SG PRESENT INDICATIVE and PRESENT PLURAL, since they are subsumed in the LP as specific items. The verbal inflex-

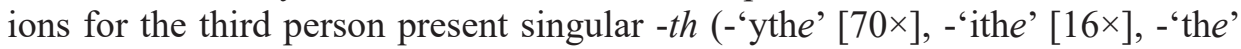

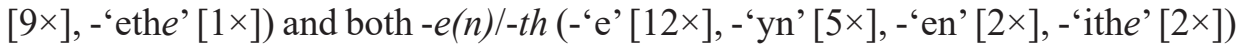
for the present plural points again both to the Midlands and the South. The area where the forms 'be' ('be' type) and 'bithe' ('bith' type) for the item ARE and the forms with double $l$ for the item EvIL conflate the most is the South.

Several items from the LP have been considered in detail as well as the range of variants (both dominant and minor) in order to register their occurrence in LALME's item maps, available in volume 2 . The first to be mentioned is the item FIRE. The forms recorded in the manuscript ('fyere' [2×], 'fyer' $[1 \times]$, 'fÿer' $[1 \times]$ ) can be found in the county of Essex (Ex). According to Brook (1978: 69-71), the dialect of Essex possessed several distinctive features and may be best considered a sub-division of South-Eastern. Some of these features, such as the lowering of $\mathrm{OE} y$ and its unrounding to $e$, which have been discussed earlier, are found in the text, whereas others are not, for instance, the development of $\mathrm{OE} \bar{a}$ to $\bar{a}$ (for $\mathrm{OE}$ clöne, we find 'clene' in the text). 
All the forms of the items FIRST ('first' $[11 \times]$, 'furst' $[1 \times]$, 'fyrst' $[1 \times]$ ) and THOUGH ('thoughe' $[2 \times]$, 'thowe' $[1 \times]$ ) are also recorded in Essex as well as 'eche', 'a yens', 'chirche', 'yen', 'lytelle', which are the single forms of the items EACH, AGAINST, CHURCH, EYES and LiTTLE, respectively. Moreover, all the forms of the item own ('oune' $[4 \times]$, 'oun' $[1 \times]$ ) functioning as an adjective, which is the only function analysed in the item maps, and of the item IF ('yf' $[28 \times]$ ) are also found in Essex. The majority of the forms of these items are located in the middle of the county and in the north-east, bordering Suffolk.

Volume 3 of LALME contains the LPs of the texts employed to produce the atlas. They are "grouped in sections, according to the county or other specified region to which their language belongs. Within each section, the LPs are ordered by key-number" (McIntosh et al. 1986, vol. 3: ix). In the item maps, the keynumber of the LPs which record specific forms are generally provided. After collating the LP of the $W B A F$ with those in the regions where items occur, for instance, LP 6070, LP 6150, LP 6300 and LP 6310, among others, the largest number of features is shared with LP 6300. These include, for instance, forms of the items THOUGH, WHERE, BUT, DAYS, EVIL, FIRE, LIVE, TWO and WHO, to name but a few (see Appendix II). LP 6300 corresponds to Cambridge, Trinity College 905 (R.14.32), a medical manuscript including John of Burgundy's Shorter Book on the Plague and plant names, among other contents. Since MS Wellcome 411 also includes materia medica, a link between the two manuscripts might be possible, but further research is necessary.

\section{Concluding remarks}

The WBAP is an illuminating example of mediaeval science. By considering one of its witnesses, MS Wellcome 411 (ff. 32r-37v), and analysing it from a threefold perspective which includes both extra-linguistic and linguistic aspects, we hope to have contributed to its study. Much work is still needed, nevertheless, on other extant copies of the text.

The allegorisations found in the text show the considerable power that religion had over mediaeval society. Still, belief in astrology and the influence of the stars and the planets was locally prevalent and, as French (2003: 134) contends, "[a] strology was fashionable throughout society in the fifteenth century and the doctor responded by adopting it as part of his clinical patter". The WBAP under consideration might have been used by a physician; the lack of decoration and the annotations in the margins bear witness to this practical function of the manuscript.

The number of general features, which are extended throughout the country, indicates that the language of the WBAP in MS Wellcome 411 is quite standardised, although specific linguistic features from the East Midlands and the South have been found. Restricting the language of the text to one of the five traditional dialects, which was one of the aims of broad localisation, has revealed that "these groupings are extremely general typological notions" and that Middle English 
materials show a dialect continuum, "rather like that of PDE spoken dialects" (Smith 2005: 119). This idea of a continuum explains why many forms are attested in several locations. Nevertheless, the results obtained from linguistic profiling and dialectal fitting suggest that it was written in the South. The conflation of forms in the county of Essex, a likely place of origin for the text under analysis, has allowed a more accurate localisation. A comparison with LP 6300, with which linguistic features are shared, also validates this hypothesis. This ascription does not exclude the possibility of encountering different dialectal layers in the text, since the scribe might have translated the language of the exemplar into his own dialect. We can suggest a fairly precise dialectal origin for the scribe of the WBAP, but not for the original author since as Lewis and McIntosh (1982: 15-16) point out "many scribes, when confronted with the task of copying a vernacular text, 'converted' it into their own form of written Middle English whatever the dialectal characteristics of the exemplar were. Orthographic conventions, whether they are of a kind which reflect some particular form of spoken Middle English or whether they are 'merely' alternative ways of symbolizing one and the same sound, differed remarkably between one place and another, even - in many areas — where these places are not very far apart".

Further analyses of the language of other copies can shed light on the production and circulation of the text during the mediaeval period. Likewise, study on the provenance of the different variant manuscript copies can give clues or insights into its textual transmission.

\section{Notes}

1 Griffin (2013: xii; xvi-xxxvi) lists thirty-four manuscripts containing the WBAP, the majority of which date from the fifteenth century.

2 Griffin (2013) provides the only critical edition to date of the WBAP.

3 David E. Southmayd (1970) edited this text for his MA dissertation at Sir George Williams University (Montreal), although the work remains unpublished. While he claims to have provided a diplomatic edition (1970: viii), the original layout, capitalisation, word division and punctuation, among other aspects, have not been respected in the edition. Besides, there is an important number of inaccuracies in the transcription.

4 According to the database description found in the "Archives and Manuscripts catalogue" of the Wellcome Library, available online at $<\mathrm{http}: / /$ archives.wellcome.ac.uk $>$, which has, in turn, been taken from Moorat (1962-1973).

5 He compiled the very influential treatise on astrology Tetrabiblios.

6 All the images hereafter are reproduced by permission of the Wellcome Library, London.

7 It does not appear in the list of items supplied by LALME.

\section{References}

Benskin, Michael (1991) The 'fit'-technique explained. In: Riddy, Felicity (ed.) Regionalism in Late Medieval Manuscripts and Texts: Essays Celebrating the Publication of A Linguistic Atlas of Late Mediaeval English. Cambridge: D. S. Brewer, 9-26. 
Brook, G. L. (1978) English Dialects. London: Andre Deutsch.

Carey, Hilary M. (2010) Astrology in the Middle Ages. History Compass 8 (8), 888-902.

French, Roger (2003) Medicine before Science: The Business of Medicine from the Middle Ages to the Enlightenment. Cambridge: Cambridge University Press.

Griffin, Carrie (2006) A Good Reder: The Middle English Wise Book of Philosophy and Astronomy: Instruction, Publics and Manuscripts. Unpublished PhD thesis. University College Cork.

Griffin, Carrie (ed.) (2013) The Middle English Wise Book of Philosophy and Astronomy. A Parallel-Text Edition. Heidelberg: Winter Verlag.

Grothé, Richard (ed.) (1982) Le ms. Wellcome 564: deux traités de chirurgie en moyen-anglais. Unpublished $\mathrm{PhD}$ dissertation. University of Montreal.

Keiser, George R. (1998) Works of science and information. In: Hartung, Albert E. (ed.) A Manual of the Writings in Middle English, 1050-1500, Volume X. New Haven, Connecticut: The Connecticut Academy of Arts and Sciences, 3593-3967.

Krochalis, Jeanne and Edward Peters (eds.) (1975) The World of Piers Plowman. Philadelphia: University of Pennsylvania Press.

Lewis, Robert E. and Angus McIntosh (1982) A Descriptive Guide to the Manuscripts of the Prick of Conscience. Medium Ævum Monographs. New Series XII. Oxford: The Society for the Study of Mediæval Languages and Literature.

McIntosh, Angus, Michael L. Samuels and Michael Benskin (1986) A Linguistic Atlas of Late Mediaeval English. 4 vols. Aberdeen: Aberdeen University Press.

Miranda-García, Antonio and Garrido-Garrido, Joaquín (2012) Text Search Engine (TexSEn). Málaga: Servicio de Publicaciones de la Universidad de Málaga.

Moorat, S. A. J. (1962-1973) Catalogue of Western Manuscripts on Medicine and Science in the Wellcome Historical Medical Library. London: Wellcome Institute for the History of Medicine.

Mossé, Fernand (1952) A Handbook of Middle English. Baltimore and London: Johns Hopkins Press.

Seymour, M. C. et al. (eds.) (1975-1988) On the Properties of Things: John Trevisa's Translation of Bartholomaeus Anglicus "De proprietatibus rerum". 3 vols. Oxford: Clarendon Press.

Smith, Jeremy J. (2005) Essentials of Early English. London: Routledge.

Southmayd, David E. (1970) The Boke of Astronomye and of Filosophye Edited from Wellcome Historical Medical Museum Ms. 411. Unpublished MA dissertation. Sir George Williams University.

Talbot, Charles H. (1967) Medicine in Medieval England. London: Oldbourne.

\section{Appendix I}

\section{LP WBAP (MS WELLCOME 411)}

THESE: pese $(9 \times)$

IT: hit $(50 \times)$, hyt $(1 \times)$, it $(1 \times)$

THEY: pey $(18 \times)$, pey $(1 \times)$

THEM: pem $(4 \times)$, hem $(2 \times)$, hem $(2 \times)$, them

$(1 \times)$

SuCH: suche $(2 \times)$

EACH: eche $(1 \times)$

MANY: many $(5 \times)$, many் $(1 \times)$

ANY: any $(4 \times)$, ony $(1 \times)$

MUCH: myche $(13 \times)$, mykelle $(2 \times)$, mykylle $(2 \times)$, mýche $(1 \times)$, mychille $(1 \times)$
ARE: be $(22 \times)$, ben $(11 \times)$, bene $(3 \times)$, bithe $(2 \times)$, bythe $(1 \times)$

WERE: were $(3 \times)$, were $(1 \times)$

Is: is $(173 \times)$, ys $(2 \times), \dot{y}$ s $(2 \times)$

WAS: was $(8 \times)$

SHALL: shalle $(64 \times)$

SHOULD: shuld $(2 \times)$

WILL: wilt $(1 \times)$, wylt $(1 \times)$

FROM: from $(2 \times)$, from $(1 \times)$

AFTER: after $(8 \times)$, aftere $(4 \times)$, after $(1 \times)$

THOUGH: thoughe $(2 \times)$, thowe $(1 \times)$

IF: $y f(28 \times)$ 
AGAINST: a yens $(1 \times)$

THERE: $\operatorname{per}(12 \times)$, ther $(2 \times)$, per $(1 \times)$

WHERE: where $(1 \times)$

THROUGH: throughe $(4 \times)$, proughe $(1 \times)$

WHEN: whan $(3 \times)$, when $(1 \times)$, when $(1 \times)$

3SG PRESENT INDICATIVE: -ythe $(70 \times)$, -ithe

$(16 \times)$, -the $(9 \times)$, -ethe $(1 \times)$, no ending $(4 \times)$

PRESENT PLURAL: -e $(12 \times)$, -yn $(5 \times)$, -en $(2 \times)$, -ithe $(2 \times)$, no ending $(1 \times)$

Past-participle prefix: ${ }^{7} \dot{\mathrm{y}}-(6 \times), a-(1 \times)$; no prefix: $(104 \times)$

ASK: askythe $(1 \times)$

BEFORE $a d v .:$ be fore $(1 \times)$, beforne $(1 \times)$; $p .:$ by fore $(1 \times)$

вотн: bothe $(2 \times)$

BUT: but $(11 \times)$
CHURCH: chirche $(1 \times)$

DAY $p l:$ : dayes $(10 \times)$, days $(2 \times)$, day $(1 \times)$, daýs $(1 \times)$

EARTH: erthe $(13 \times)$, eyrthe $(1 \times)$, yerthe $(1 \times)$

EVIL: evylle $(10 \times)$, euylle $(3 \times)$, evelle $(2 \times)$, eville $(2 \times)$

EYE $p l:$ : yen $(1 \times)$

FIRE: fyere $(2 \times)$, fyer $(1 \times)$, fÿer $(1 \times)$

FIRST: first $(11 \times)$, furst $(1 \times)$, fyrst $(1 \times)$

GO: goythe $(6 \times)$, goithe $(2 \times)$, go $(1 \times)$, goo $(1 \times)$

LITTLE: lytelle $(4 \times)$

LIVE $v b$ : lyue $(3 \times)$, lyve $(1 \times)$

own adj: : oune $(4 \times)$, oun $(1 \times)$

TWO: too $(1 \times)$

WHO: who so $(16 \times)$, ho so $(5 \times)$, whoso $(2 \times)$, ho $(1 \times)$

\section{Appendix II}

\begin{tabular}{|c|c|}
\hline LP $W B A P(M S$ WELLCOME 411) & LP 6300 (LALME, vol. 3, p. 127) \\
\hline $\begin{array}{l}\text { THEM: pem }(4 \times) \text {, hem }(2 \times) \text {, hem } \\
(2 \times) \text {, them }(1 \times)\end{array}$ & THEM: hem \\
\hline EACH: eche $(1 \times)$ & EACH: iche, yche, eche \\
\hline MANY: many $(5 \times)$, many் $(1 \times)$ & MANY: many (mony) \\
\hline ANY: any $(4 \times)$, ony $(1 \times)$ & ANY: ony \\
\hline Is: is $(173 \times)$, ys $(2 \times)$, ys $(2 \times)$ & IS: is \\
\hline FROM: from $(2 \times)$, from $(1 \times)$ & FROM: from, fro \\
\hline THOUGH: thoughe $(2 \times)$, thowe $(1 \times)$ & THOUGH: though, thowe, thow \\
\hline IF: yf $(28 \times)$ & IF: if (yf) \\
\hline AGAINST: a yens $(1 \times)$ & AGAINST: a-gayne, ayeyne, ayens \\
\hline WHERE: where $(1 \times)$ & WHERE: where \\
\hline вОтн: bothe $(2 \times)$ & BOTH: bothe, both \\
\hline BUT: but $(11 \times)$ & BUT: but \\
\hline $\begin{array}{l}\text { DAY pl.: dayes }(10 \times) \text {, days }(2 \times) \text {, day } \\
(1 \times) \text {, daẏs }(1 \times)\end{array}$ & DAY $p l .:$ dayes \\
\hline $\begin{array}{l}\text { EVIL: evylle }(10 \times) \text {, euylle }(3 \times) \text {, } \\
\text { evelle }(2 \times) \text {, eville }(2 \times)\end{array}$ & EVIL: euyll (euyle) \\
\hline FIRE: fyere $(2 \times)$, fyer $(1 \times)$, fÿer $(1 \times)$ & FIRE: fyer \\
\hline LIVE $v b .:$ lyue $(3 \times)$, lyve $(1 \times)$ & LIVE $v b .:$ lyue \\
\hline TWO: too $(1 \times)$ & TWO: twoo, too \\
\hline $\begin{array}{l}\text { WHO: who so }(16 \times) \text {, ho so }(5 \times) \text {, } \\
\text { whoso }(2 \times) \text {, ho }(1 \times)\end{array}$ & wHO: ho-so, qwho-so, who-so \\
\hline
\end{tabular}

Laura Esteban-Segura is a Senior Lecturer at the Department of English, French and German Philology of the University of Málaga. She received her PhD in English Linguistics from the University of Málaga in 2008. She also holds BA degrees in English Philology (2002) and Translation 
and Interpreting (2004) from the above-mentioned university and a Master of Letters in English Language and English Linguistics from the University of Glasgow (2008). Her main research interests lie in the History of the English Language, Textual Editing and Manuscript Studies. The more specialist aspects of her research focus on the study of unedited medical manuscripts in Middle and Early Modern English. She has published in specialised journals such as English Studies, Neuphilologische Mitteilungen, Studia Anglica Posnaniensia and Manuscripta, among others.

Address: Dr Laura Esteban-Segura, Department of English, French and German Philology, Faculty of Philosophy and Arts, University of Málaga, Campus de Teatinos, Málaga, 29071, Spain. [email: lesteban@uma.es] 